\title{
AN ANALYSIS OF CULTURE AS A TOURISM COMMODITY
}

\author{
AGATA MACCARRONE-EAGLEN
}

Salford Business School, University of Salford, Salford, Greater Manchester, UK

\begin{abstract}
Thenotion of culture has been the object of multidisciplinary studies attempting, with difficulty, to define this polyhedral social concept expressed in symbolic representations. Culture has a significant role in tourism functioning as an internationally promoted commodity, a role that has often been the subject of debates among academics concerned about the vilification of culture's primary social role. This article analyzes the complexity of the concept of culture in combination with the characteristics of a product, as conceived in marketing, focusing on the levels of product theory from Kotler and Armstrong. The research is based on secondary data analysis in the discussion. This incorporates culture's symbolic representations, its tangibility and intangibility, its multiplicity of interpretations and meanings, the ambiguous status of ownership by the buyer and its versatility to satisfy consumers' needs while functioning as a unit of identification for a society. As a product culture presents a unique configuration with a construct of four different dimensions highlighting the need for special consideration in culture's marketing process. The research could also be considered as a platform for future investigations on the subject and as supporting material in education.
\end{abstract}

Key words: Culture; Product; Commodification; Symbolic representation

\section{Introduction}

The concept of culture appears to be complicated and multifaceted and has been examined in a number of academic disciplines such as anthropology (Pieterse, 1995), sociology, philosophy (Lloyd \& Thomas, 1998), and management (Richards, Goedhart, \& Herrijgers, 2001). Studies have also analyzed the relationship between tourism and culture as a symbiotic combination generating "cultural products" or commoditized culture (Robinson, 1999). However, little attention has been directed to the analysis of the characteristics of culture from a marketing point of view when culture becomes a product. In fact, Carter and Beeton (2004) and Robinson (1999) refer to cultural products commodified for tourists; however, a question arises when considering the variety of meanings of culture and, then, what the product is when referring to cultural products.

According to Richards et al. (2001) and McKercher, Ho, and du Cros (2004), it seems that there is limited understanding of what is packaged as culture by the sellers of culture, in particular when this is promoted across the international tourism markets. In addition, Dann (1997) under- 
lines the limitation of systematic studies on promotional material that advertises tourist destinations and local culture with a restricted knowledge by the promoters based, in some cases, on a oneoff individual experience of a destination context. Therefore, this article aims to marry the concept of culture with the concept of product in order to explore the profile that culture might have when used as a commodity for sale. This would contribute to enlighten the process of promotion and benefit scholars, researchers and students, as future marketers of culture in the tourism industry, in further understanding the concept of culture as a product.

The research is based on secondary data by analyzing a review of specific literature that contextualizes culture, its role and its idiosyncratic attributes. This information will be discussed and integrated in the light of theories on product marketing borrowing, in particular, Kotler and Armstrong's (2008) presentation of the levels of product, because this provides a simple though structured approach to the study of product. In addition the article refers to the semiotic analysis of part of a brochure issued by VisitBritain, the British National Tourist Authority, in which "cultural products" are promoted, exclusively with the purpose of corroborating the discussion with examples taken from the activities of a recognized body, in order to clarify some relevant points.

The rationale for this lies in the facts that: semiotics is the study of sign and codes (Fiske, 2001); that culture is the result of the interaction of symbols used to communicate (Jenks, 1995; LeedsHurwitz, 1993); that tourism studies adopt metaphors and metonyms to portray concepts and social constructs (Dann, 2002); and that studies in marketing and consumer behavior are increasingly adopting this technique especially in advertising (Mick, 1986; Echtner, 1999; Dann, 1997).

\section{The Concept of Culture}

The origin of the word culture is claimed to derive from the concept of "cultivation of nature" applied to "cultivation of humankind," which can be expressed as "the ensemble of artifacts and aesthetic practices of a developed civilization" (Lloyd \& Thomas, 1998, p. 2), therefore implying educa- tion, communication, and transformation. According to Fan (2000), culture originated instead from the Latin word "cult," meaning worship, attributing to culture the idea of rituals and consequently coded behavior shared across the members of a group. Similarly, Jenks (1995) and Groeschl and Doherty (2000) identify culture as an element of integration for the people of a society through signs and symbolic representations that are recognized and adopted spontaneously by the members of a society (Jenks, 1995), though not genetically transmissible (Eagleton, 2000).

An anthropological view of culture defines it as "whatever is distinctive about the 'way of life' of people, community, nation or social group" (Hall, 1997, p. 2) within which diversities of conception of life and interpretation of meanings could coexist (Hall, 1997). However, according to Pieterse (1995), culture appears twofold; on one hand it implies territoriality and therefore limitations and traditions, and on the other hand it could exist in a larger context across and above circumscribed cultures due to human interactions. Languages are examples of a changing system of cultural signs operating within a social context (Hall, 1997) and also of the reflection of the phenomenon of acquisition of signs and transformation of culture (Jenks, 1995).

These definitions, however, appear to have changed from traditional anthropology that considered culture as a strictly clustered set of symbolism, unconsciously accepted and assumed by a group of people (Yamashita, 2003), stressing, therefore, differences and similarities between those groups (Lawton, 1975). Thus, culture is often linked with the concept of "State" because it implies the entirety of conceptions of the people of a country, though some postmodern scholars claim that culture has loose delimitations (Featherston, 1995). Reisinger and Mavondo (2006) allege that the culture of a nation could be identified in the dominant cultural features of a group living within State boundaries, implicitly acknowledging subcultural groups and "individual culture" within the same territory. However, culture interpreted in this sense might change over time as exchanges of values and practices might occur across populations due to traveling, dominations, business, and education (Jenks, 1995). Hence, the claim from Me- 
dina (2003) that the term culture should consider something that exists within a community at any time, not just specific or past practices and objects.

Culture has been also classified in two further definitions generally known as "high" and "low" culture (Storey, 1996). The term "low culture" or "popular culture" implies everyday practices and beliefs of a group of people that distinguishes societal members with unique characteristics. Therefore, slow changes of the group members' behavior may have repercussions for the uniformity that gives identity to the idea of culture (Wallerstein, 1995) underlining the previously mentioned phenomenon that culture's dynamic essence is neither stable nor an objective reality (Fiske, 1996). High culture, in contrast, refers to different expressions of classic literature, philosophy, and arts; therefore, it concerns the outcomes of higher human intellect and development (Hall, 1997). However, the terms "high" and "low" culture express a controversial issue since it seems to attribute to culture connotations of superiority or inferiority. Ironically, this indicates an apparent division instead of the sense of belonging that culture is purported to represent. However, it is presumed that no mind can exist without body and vice versa (Wallerstein, 1995).

\section{Tourism and Culture's Commodification}

Both high and low culture can be motivators for tourists seeking to learn and/or to specifically participate in cultural events and visit historical and artistic sites (Craik, 2001), activities that are allegedly undertaken by educated people whose primary motivation to travel is knowledge (Richards, 1996a) or learning a language, the way of communicating of a social group (Kennett, 2002). The interest of tourists in the desire of experiencing a different lifestyle has also grown, for example, as with national or regional gastronomy as in the case of Italy, where food is deemed to be a cultural icon (Hjalager \& Antonioli Corigliano, 2000). However, cultural experiences might also be embedded in the tourists' experience of those tourists whose primary purpose for tourism may not be knowledge and erudition (Craik, 2001). Consequently, culture has been directly and indirectly, the generator of substantial economic bene- fits for communities because of tourists' spending (Edson, 2004), while representing the emphasis of social differences (Besculides, Lee, \& McCormick, 2002).

However, the use of culture for the benefit of the tourism industry has generated other debates around a process described as commodification (or commoditization), which Medina (2003) states is "the offering of cultural products and practices for money" (p. 2). "Commodification is generally taken to be the process whereby ways of life, traditions and their complex symbolism are imaged and transformed into saleable products" (Robinson, 1999, p. 11), with tangible and intangible qualities (Carter \& Beeton, 2004; Medina, 2003).

Therefore, commodification has socioeconomical effects as it generates incomes and sustains a community by preserving traditions used to generate revenues (Richards, 1996b; Silverman, 1999). For example, the Mestizos, in Mesoamerica, claim to perpetuate the Mayan culture by producing handicrafts, with the help of archaeologists and the tourism industry (Medina, 2003), while the inhabitants of the Evangeline region in Canada utilize their French Arcadian culture as a Unique Selling Proposition (MacDonald \& Joliffe, 2003). However, the selling of "cultural products" to fuel the tourism market may create problems in the relationships between host and guests (Duggan, 1997; Richards, 1996b; Shepherd, 2002) or they might induce communities to economically depend on tourism (MacLeod, 2006).

Commercialization of culture for economic purposes is also believed to deprive culture of its meaning and role of providing individuals with identification and belonging. In fact, a weak form of commodification is attributed to high culture, as historical features and arts will supposedly remain of the same value whether or not they are used to attract tourists. A strong form of commodification, is, instead, attributed to low culture because current or past popular rituals, habits, and ways of life, with intrinsic values for the holders, may become devalued when transformed into objects for sale or when they are reconstructed for the tourists (Robinson, 1999). Commodification of culture, from these perspectives, may appear to imply negative connotations.

Halewood and Hannam (2001) also analyze 
commodification considering two perspectives. One perspective identifies commodified culture with nostalgia, which contributes to maintain cultural values and diversity. The second perspective (also endorsed by Besculides, Lee, \& McCormick, 2002; Carter \& Beeton, 2004; McIntosh \& Prentice, 1999; Richards, 1996a), identifies commodified culture with the concept of "inauthenticity," which is also blamed for depriving culture of its original value because it refers to reproduced past performances of former traditions of a society for the benefit of tourists rather than for the fulfillment of societal needs.

However, as Shepherd (2002) suggests, if authenticity is considered as synonymous with originality, authenticity of culture could only be found in the first symbolism that was adopted as an aesthetic formulation of behavior of a social group; therefore, authenticity of culture, in this sense, is almost impossible to be achieved. Moreover, Reisinger and Steiner (2006) strongly endorse the idea of discarding the concept of object authenticity within a dynamic social reality, where it is impossible to attribute a unique and indisputable meaning to a symbolic representation of a social group. Interestingly, Kasfir (1999) and Salomon (2001), instead, highlight that reproduction of symbolic representations of a society may "paradoxically" also have meanings for the tourists; this significance can be private and related to a personal interpretation; hence, reproduction aims to stimulate feelings and memories.

\section{Culture as a Tourism Product}

The contentious opinions of the extent to which culture may become a saleable "item" might be reunited under the Kotler, Armstrong, Saunders, and Wong (1999) definition of product as "anything that can be offered to a market for attention, acquisition, use or consumption that might satisfy a want or need. It includes physical objects, services, persons, places, organizations and ideas." (p. 561). This inclusion of "anything" reinforces the idea that culture can assume the function of a commodity, though Greenwood (1989) argues that this "anything" is typical of capitalist societies that exploit culture, considering it as a natural resource even though culture does not appear to be the re- sult of the combination of the factors of production: land, labor, and capital.

However, it is evident that culture fulfills this role, by and large, because culture is conceived as having territoriality (land). In fact, Featherston (1995) refers to culture as the State, supported by Hall (1997) and Jenks (1995) who consider culture as the way of life, beliefs, and practices (capital) of a given society (labor producing culture), which, by definition, live in a space or land.

Middleton and Clarke (2001) clearly categorize culture within a cluster of tourism products whose marketing, according to Dietvorst (1994), is subjected to the environment in which these products are consumed, which, in consequence, may affect the perception of them by tourists. These, in turn, are affected by their cultures, that, according to Kale (1991), may also be assimilated to a screen that filters the reception of messages and information based on parameters encoded in the signs of the culture to which an individual belongs. In addition, according to Paliwoda and Thomas (1999), although coded messages are transmitted through symbolic representations, which make specific meanings perceptible, the promotional practice of culture cannot invent anything new but borrows themes from every day life.

These themes or plurality of elements of culture (Odimu, 2002) are those used by marketers in promotional materials to reach consumers, a practice that has been heavily criticized by Desmond (1999), who considers that images of symbolic representations of culture could be catalytic for "an active process of decontextualizing, iconicizing, and decontemporizing" (p. 102). This concept is reinforced by MacLeod (2006), who claims that knowledge of culture could make a difference to the experience of both tourists and locals. This process might pass unobserved by less informed tourists, though it could disillusion the more knowledgeable.

Interestingly, Bourdieu, in Richards (1996b), considers that the consumers of culture should also have the cultural capital, or knowledge, in order to appreciate the product and participate in the consumption. Richards (1996b) also mentions that research demonstrates that there is a direct relationship between demand for cultural products and the level of scholarship of the consumers. This 
theory is corroborated by Kim (2005), who alleges that the most erudite consumers of culture are education driven and often use their knowledge to compare past and present. Nevertheless, according to Robinson (1999), market research on international consumers of culture generally does not refer to the influence of education, occupation, and social class; therefore, it appears that the promotion of culture is addressed to a wide, apparently undifferentiated audience.

McKercher et al. (2004) consider that insufficient information on culture from the marketers might negatively impact on the product itself and on the meanings of culture. Moreover, Richards et al. (2001) allege that knowledge of culture on the supply side seems limited, in particular referring to mass tour operators, while specialized operators may appear to have a higher cultural knowledge; therefore, a deeper understanding of culture might have implications for marketing activities. Burns (2005) in fact considers that an understanding of culture as a product could not solely improve the message to consumers, minimizing the risk of inflating or deflating the value of the product but, also, would lead host populations and consumers to refer to the same interpretation of meanings. As culture represents and contains values (Featherston, 1995; Hall, 1997; Jenks, 1995; Lloyd \& Thomas, 1998; Odimu, 2002; Richards, 1996a), it is essential that marketing should not be based on a superficial knowledge of the product.

In addition, the need for practitioners to understand the marketing environment is fundamental. Hence, the role of marketing education is to provide the industry with individuals who substantiate their activities with knowledge acquired by analyzing the marketing setting (Aistrich, Saghafi, \& Sciglimpaglia, 2006) and develop creative thinking for marketing activities and stimulate curiosity in consumers (Hill \& McGinnis, 2007). Particular attention, within tourism marketing, should be given to culture as it is marketed across cultures (Burton, 2005).

\section{Discussion: The Commodity Culture}

It is important to consider that, if "anything that can be offered to a market for attention, acquisition, use or consumption that might satisfy a want or need. It includes physical objects, services, persons, places, organizations and ideas" (Kotler et al., 1999, p. 561), then culture as a product might be subjected to a transaction in the market; therefore, it is useful to analyze what is transferred to the consumer by the seller when the focus of the deal is culture.

\section{Ownership of the Sold Product Culture}

A British castle or the work of artists, if referring to high culture, can be physically touched and seen but not owned by the tourist who has bought the experiences as cultural products. The "sale" is, therefore, externalized with a service, for example access to a site or a guided tour. Consequently, the product culture acquired is cognitive merchandise, an experience, not a material product nor a service, though expressed through a service. Even in the case of souvenirs, tourists do not appear to buy culture, but an item that is reminiscent of a culture, which they have in some ways emotionally experienced. Souvenirs, in fact, represent the product culture out of its context, in particular, when the tourists return to their original habitat.

In addition, as Lee and Littrell (2003) and MacLeod (2006) suggest, some cultural items are also purchased out of their production environment as in the case of ethnic clothing traded internationally. However, with regards to these latter products, it can be argued that, although, a symbolic representation of a culture is acquired, the benefit appears not to be a direct participation in that culture, but the "nostalgia," which Kim (2005) associates with the wish to indirectly participate in a learned (or wanted to learn) cultural context. The acquisition of the product, consequently, can be seen, again, as a cognitive possession.

Therefore, the extent to which a tourist might "own" the product culture during their experience of "immersion" in a cultural context might be related to the acceptance and acquisition of those practices, values, and shared customs that they wish to retain and apply to their everyday lives, once out of the place where they had the cultural experience. Nevertheless, the ownership of the commodity culture could also be seen in the consideration of Kennett's (2002) assertion of language learners becoming bicultural. In this spe- 
cific instance, in fact, the tourist acquires the usage of symbolic representations (words and expressions) of the culture of a different group, which, when sold, is also manifested through a service provided, for example, by language schools.

\section{The Four Dimensions of the Product Culture}

Culture, as a product, therefore manifests specific characteristics that, when reconfigured, create a different entity from the classic concepts of product or/and service, though it seems to have features of both. The analysis that follows has been condensed and represented in a model (Fig. 1), which should function as a visual aid to illustrate the characteristics of culture as a product. This is in line with Clarke III, Flaherty, and Yankey's (2006) view that visualization of concepts offers significant assistance in the explanation and retention of information.

The model is developed on the basis of Kotler and Armstrong's (2008) levels of product theory (Fig. 2), which elaborates and presents the basic concept of product as having three different dimensions. The first central feature is the "core" product, that which is bought by the consumer in terms of benefit(s) gained; the second level, the "actual product," relates to what identifies and distinguishes the product in the form of package, quality, style, physical features, and brand. The third level, the "augmented product," consists of the additional elements and benefits to the core product.

\section{The Essence of the Commodity Culture}

The core product, as stated by Kotler and Armstrong (Fig. 2), refers to that which the consumer receives to fulfill a need-in other words, an individual benefit. In the case of culture, the fundamental benefit, therefore the "essence of product" in Figure 1, could be seen in the satisfaction of the

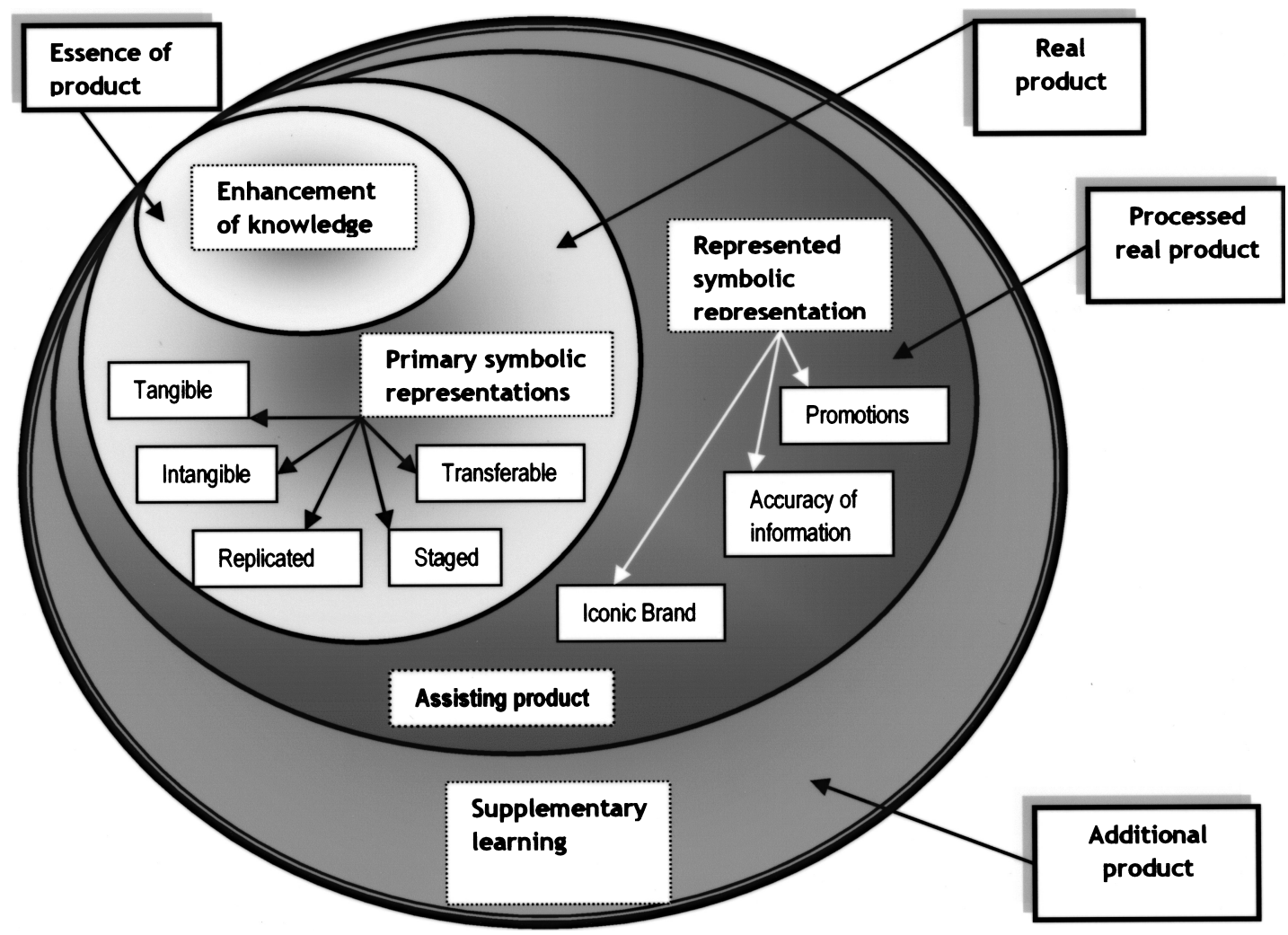

Figure 1. The four dimensions of the product culture. 


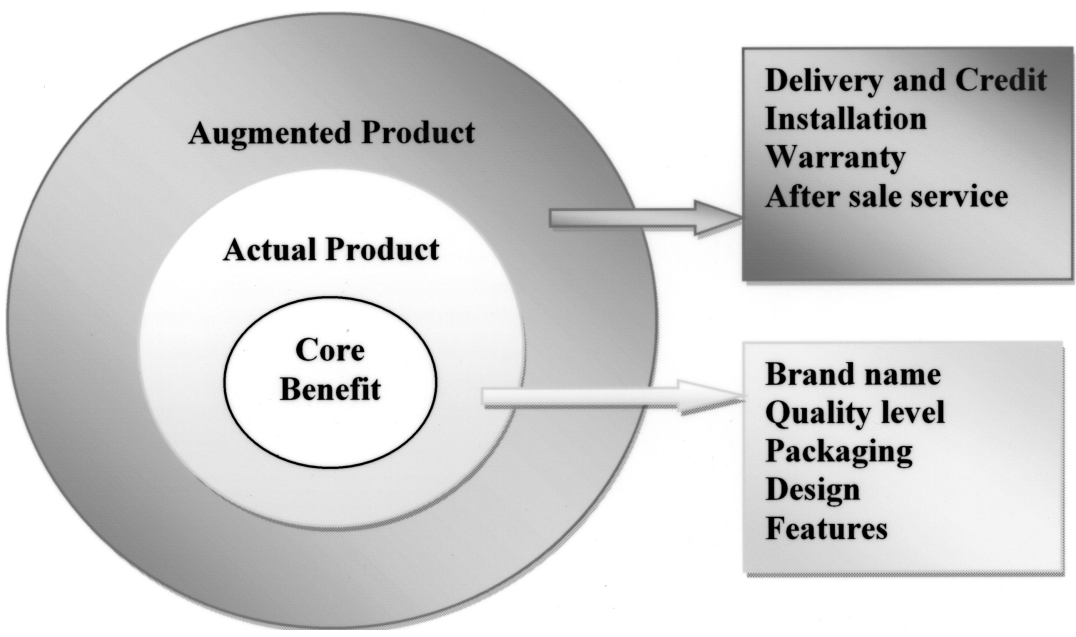

Figure 2. Three levels of product. Source: Kotler and Armstrong (2008, p. 220).

need for knowledge. In the case of the purchase of high culture (e.g., art), the essence could be related to the understanding of art techniques and values; while in the case of low culture the essence could be the understanding of the relations of a different population. Therefore, the "essence" of the product culture could be construed as the result of the satisfaction of the need of interacting and understanding different social realities in the environment where those social realities normally take place. Consequently, that can be defined as countries of production, because consumption and production of the product culture are generally not spatially separated. Exceptions, in fact, could be found in what is indicated by MacLeod (2006) as the international trading of ethnical items (also through internet websites) for consumption outside the country of origin.

The satisfaction of the consumer needs could also be summarized as "education"; this implies enhancement of viewpoints, widening of horizons, development of skills, awareness and analysis, retention or rejection of information received. For example, VisitBritain's brochure "Hidden Britain" (2001) promoted, among other elements of culture, British castles, which, according to market research are the symbolic representations of "British culture" in highest demand (Flack, 2007). The picture of a castle is also the first symbol in the online campaign related to a recent film titled
"Elizabeth: The Golden Age" on the life of Queen Elizabeth I (VisitBritain, 2007a). Therefore, the "essence" of the product culture gained by tourists undertaking a visitation to a castle, experiencing high culture, might lie in the learning from the simple understanding of the existence of the castle to the details of the architecture, the historical use of the castle, and the people living in it. In addition the level or depth of knowledge gained may be related to the level of personal involvement in the experience and individual motivation.

\section{The Real Product of the Commodity Culture}

The second level of product identified by Kotler and Armstrong (2008) is the actual product. This encompasses those features that distinguish a product from others in the market; therefore, it represents the area where the marketing activity may be designed to influence consumer behavior. It is identified by visible, tangible, and projected features of a product that can be perceived and evaluated by consumers: the package, quality, style, physical feature, and brand. However, in the case of culture, as Paliwoda and Thomas (1999) state, marketers cannot reinvent anything new but use what is in place already. In fact, they can only market and "sell" those symbolic representations that exist "naturally" and what Richards (1996a) defines as the technical and conceptual dimensions 
of culture. The technical dimension refers to sites, monuments, and high culture; the conceptual dimension, instead, is related to low culture and it is also considered ethnic tourism. Some scholars, such as Kim (2005), Richards (1996b), and MacLeod (2006), define those aspects of culture as "cultural products" or "elements of culture."

Therefore, if considering the physical and functional attributes of culture's symbolic representations in the light of the literature and the previous discussion, it is possible to classify those symbolic representations into clusters. These may reflect the concept of "product lines," which Andreasen and Kotler (2003) define as those groups of products whose "product items" have common characteristics. In the case of culture, therefore, it can be argued that symbolic representations with common attributes could be clustered into culture's product lines, from which marketers and operators select their "product mix" to be sold to tourists. Hence, the following product lines are proposed for the product culture as components of the "real product" in Figure 1:

1. Tangible symbolic representations: consisting of those "product items" that can be physically experienced and seen, such as places, archaeological sites, ruins, buildings, and their architecture and pieces of artistic creations.

2. Intangible symbolic representations: which signify knowledge and values, although they may have a tangible aspect, for example books containing intangible knowledge expressed in literature, history, and practices that the owners of that culture may share in everyday life.

3. Staged symbolic representations: which are characterized by those expressions of beliefs and arts that are manifested with specific performances, such as music, dance, drama, events, and pilgrimages, which could be contemporary or past.

4. Replicated symbolic representations: these are embodied into items having the function of reproducing a given symbolic representation, such as souvenirs, prepared by the culture's holders, whose function may be to remind tourists about the experience of interaction with a culture.

5. Transferable symbolic representations: being those popular aspects of culture that might be acquired by an individual by being involved within a culture or studying a language.

These lines of products could be defined as "primary symbolic representations" of culture as a product because they reflect contexts in real life, though consequently they might change over time, developing due to the dynamic essence of culture.

\section{The Processed Real Product of the Commodity Culture}

Because, in principle, the real product culture could not be modified by marketers who have to borrow product items from the product lines of culture; marketing interventions via promotional activities add another dimension to the real product: the processed real product of the commodity culture (Fig. 1). This could be seen as the area of the product culture that includes the epitomized and interpreted symbolic representation of culture by marketers - in other words, symbolic representations of symbolic representations!

To illustrate this third dimension of the product culture, this article uses an example of promotional material by VisitBritain (2001) (Fig. 3) from their brochure "Hidden Britain," of which the central picture of a castle (symbolic representation) is analyzed with semiotic techniques emphasizing the transmission of meanings via promotional activities. The choice for the British National Tourist Authority's material lies in their approach to promotions of culture, in particular because they operate as those that Morales Cano and Mysyk (2004) define mediators of the patrimony of a society.

The previously mentioned arguments might also advocate that the symbolic representations of culture would need to be accurately featured in order to emulate the meanings of the "primary" symbolic representations. This activity, in fact, as Dann (1997) alleges, represents a concern because of the limited knowledge by tourism operators, who, according to what is asserted by McKercher et al. (2004) and McLeod (2006), as the suppliers of culture should be knowledgeable about the product they offer. However, it may be also important to consider that the expertise of the sellers would also reflect the evolution of the product and 
Analysis of the symbolic representation of a symbolic representation (the castle)

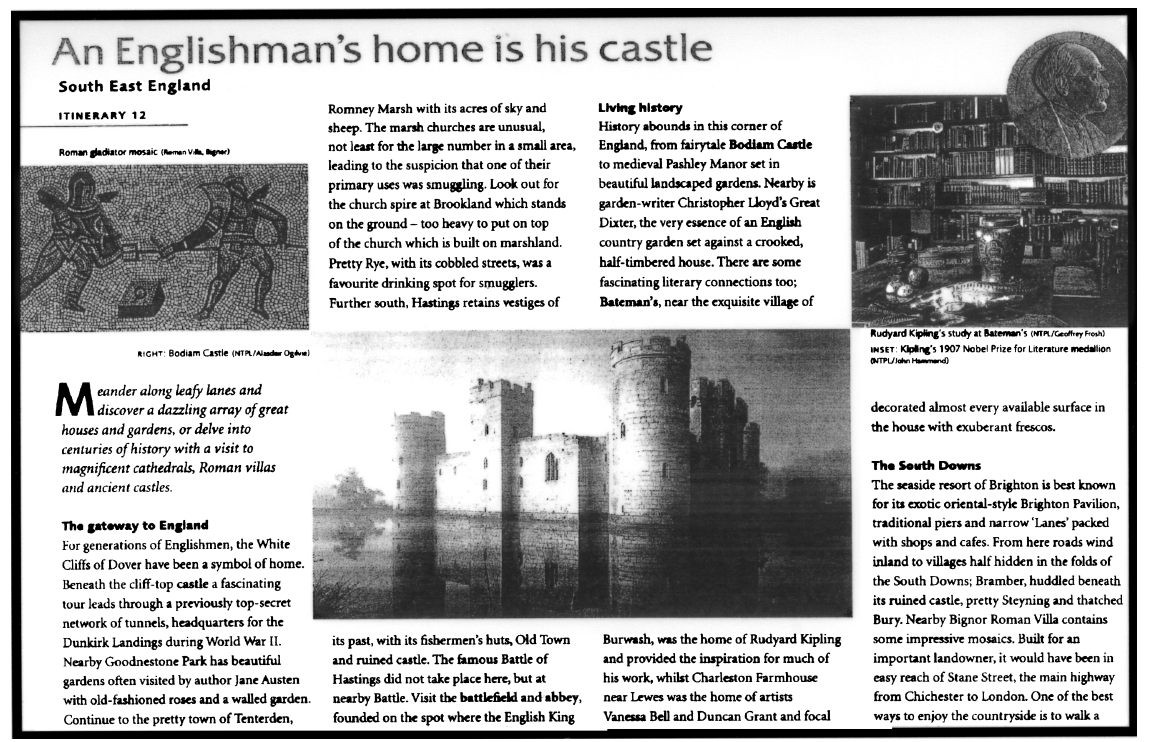

The picture catches the iconic image of a castle in mist, which might indicate indistinctness, however symbolizing home and territoriality. It stands alone and well preserved in the countryside and it may be an isolated and mysterious place still in use. If other buildings could be seen it would no longer be a mysterious place but part of an urban community and if in ruins it would be partially visible inside and not very secretive.

The picture focuses on a corner of the castle to highlight its massive dimension and arousing curiosity as to its history; if the picture would be frontal, it would not adequately portray the dimensions of the castle.

Dawn or sunset colors in a mist could indicate mystery and a prelude of perhaps day or night; therefore, weather dawn or dusk, it might inspire curiosity or anticipation. If the picture would be taken at night it could indicate fear, strong mystery or horror and if taken during the day it would indicate clear vision and control.

The castle is surrounded by water, again portraying a possibly inaccessible or secret place, whilst the reflection of the castle in the water is like penetrating the depth, almost having roots. If there was no water reflection could make it appearing 'normally built'. If a bridge or a boat would be in the picture this might mean accessibility and communication with the outside world. Finally, no human or animal presence is in the picture, suggesting the enigma of who was or could be inside; however a human presence would unveil the enigma of possible activities in the castle (military, royal, magic, ghostly).

The castle is portrayed creating a puzzling atmosphere which stimulates imagination on the activities and people in this particular place. The combination of the signs in the picture may depict the myth around ghosts in the English castles. This scenario, denied by possible alternative signs, may arouse curiosity in the observer being enticed to visit the place and to know more about it.

In addition, in the written passage castles are mentioned four times describing something particularly English; it refers to castles as 'ancient', 'ruined', and 'fairytale castle', indicating the mystery associated with them, myths and stories that add to the culture of the country. Not having this emphasis in the passage, it would probably exclude a substantial proportion of the heart of the English culture. In addition the castle occupies the centre of the page, putting emphasis on the qualities that the words attribute to it.

The chain of meanings appears to be grounded in history through the interaction of the functions of picture and text in a concise description encapsulates an English side of the British cultural patrimony. The message stems around a time without time, attracting the observer to experience the place and learn more about this aspect of English culture.

Figure 3. Example of promotion culture. Source: Visit Britain (2001, p. 28). 
the stage of its components' life cycle so that culture could still reflect the social context that created its values.

The "processed real product" culture encompasses also the brand, which, according to Middleton and Clarke (2001), is one of the most important product features in marketing activities as it indicates ownership of the product. It also symbolizes a degree of quality, distinguishes a product from the competitors, and, as specified by Andreasen and Kotler (2003), helps the consumer to identify the product.

Culture also appears to be subjected to branding to provide tourists with an image or meaning that could identify the population of a country representing what tourists might conceive as distinctive connotations of that population and their lifestyle (VisitBritain, 2007b). The National Tourist Authority for Britain has, in fact, been promoting the brand "hearth, depth and vitality" to signify the values of the British nation (VisitBritain, 2005a), providing a feeling of British identity, in particular, to the international tourism market. From the analysis of the castle in Figure 3, it seems like the brand is surfacing from the blending of feelings transmitted through the representation of culture in the image, notwithstanding the fact that representation of culture appears anyway to be subjected to the unavoidable process of individual interpretation and perception by the involved stakeholders.

The "processed real product" of the commodity culture would not be completely represented without that element addressed as the "assisting product" (Fig. 1). In fact, the tourism products, in particular, received further attention by Kotler, Bowen, and Makens (2006), who, based on Gronroos'(1987) theory, present their analysis referring to the characteristics of heterogeneity and intangibility of a service product. In this context they consider two more elements: the "facilitating products," consisting of the services to access the core product, and the "supporting products," being the extra services to ameliorate the quality of the core product.

Being the symbolic representations of culture accessed through intangible services-for example, a guided tour - the suppliers of both high and low culture might provide the "assisting product," which, in this instance, could be seen in those services that allow and help accessibility to culture and, therefore, connect the supply chain of culture to its demand.

\section{The Additional Product}

of the Commodity Culture

Kotler and Armstrong (2008), in Figure 2, refer to the augmented product, when considering the additional benefits and services added to the core. Kotler, Bowen et al. (2006) also define the augmented tourism products as the "physical environment, customer interaction with service delivery system, customer interaction with other customers, customer co-production." (p. 305). However, when examining culture and considering its nature composed of symbolic representations, the additional benefits to the essence of product could be seen in any additional knowledge derived from the experience of culture.

These supplementary benefits, or "additional product" (Fig. 1) to the central experience and knowledge, could be found in a further enhancement of learning by the consumer. This might be due to the relationship and interaction of the symbolic representations with a variety of disciplines and themes-for example, the acquisition of an understanding of construction engineering while touring to see the architecture of castles.

\section{Conclusion}

The process of adopting the polyhedral concept culture as a commodity across cultures has been the object of controversial debates. It has been asserted that culture's function as a product could compromise its intrinsic value, in particular, because some scholars have identified and agreed that generally little knowledge of the product underpins culture's marketing operations.

Special qualities distinguish culture from other products: culture is actualized by encoded meanings in symbolic representations; it is externalized with tangible and intangible elements; it covers a range of components in its represented product mix. Moreover, its production is not always related to a distribution chains. The ownership of the acquired product is prevalently related to the gaining of knowledge rather than possession of the 
product transferred from suppliers to consumers. Its consumption is related to acquisition of knowledge within a cognitive interpretation of individual sensorial experiences. Finally, the intrinsic nature of culture is that it changes over time and it is also surrounded by a halo of relativity of the meanings attributed to its components, not only because it is subjected to changes, but also because it is subjected to personal understanding by individuals belonging to a culture, tourists and marketers.

Therefore, this research has integrated the characteristics of the concept of culture with the structure of product as conceived in marketing, elaborating a unique configuration for this commodity. The features are condensed in a model (Fig. 1) that identifies four different dimensions for the product culture. The representations of these dimensions should enlighten promotions and support studies of the subject. The proposed model of culture as a product, in Figure 1, encompasses four dimensions identified as: the essence of product, the real product, the represented real product, and the additional product.

The expressions of culture are, in fact, communicated through symbolism decoded by the culture's holders and these cannot be transferred or modified by marketers, but only interpreted and presented with symbolization of symbolic representations. Hence, the challenges when culture is marketed may be twofold: on the one hand, the marketing process should provide the closest possible representation of the product, which, by implication, means more accuracy of information and transmission of the essence of the product. This could provide consumers of culture with what they demand as the ultimate function of marketing. However, on the other hand, it could prove difficult for organizations to understand consumers' needs in terms of culture as a product, hence the need for cross-cultural marketing consumer research. This is in line with Kale's (1991) view that culture acts as a filter in the consumer's mind and also in agreement with Engel, Blackwell, and Miniard (2001) alleging that culture influences consumer behavior.

However, culture shows a paradoxical contradiction and versatility as a product, it encompasses creativity, way of communicating and lifestyle of a society, and therefore portrays an idea of a stable unit that cannot be unpackaged in consideration of the preferences of the consumers. Simultaneously it seems that as a product it is adaptable to the taste of consumers belonging to different cultures. Promotions, therefore, should target consumer segments according to their nationalities (VisitBritain, 2005b).

Marketers and scholars might, therefore, have to consider that the approach to marketing for the product culture should be different from the approach to other products or services because of the complexity of the concept of culture and its structure when adopted as a commodity for tourism.

Culture's uniqueness and flexibility demonstrates another manifestation of its ability to satisfy human needs to develop and understand the world in which they interact. Hence, ironically, commodified culture can be intended as sustainably fulfilling its social function by invigorating the sense of community and belonging, whilst contributing to economic benefits.

\section{References}

Aistrich, M., Saghafi, M. M., \& Sciglimpaglia, D. (2006). Ivory tower or real world: Do educators and practitioners see the same world? Marketing Education Review, 16(3), 73-80.

Andreasen, A., \& Kotler, P. (2003). Strategic marketing for nonprofit organizations. Upper Saddle River, NJ: Pearson Education Inc.

Besculides, A., Lee, M., \& McCormick, P. (2002). Residents' perceptions of the cultural benefits of tourism. Annals of Tourism Research, 29(2), 303-319.

Burns, P. (2005). ATLAS Special Interest Group: Tourism and Socio Cultural Identities Research Group. Annual review of activities 2005. Retrieved from http://www.at las-euro.org/SIG/Identities/identities_introduction.htm

Burton, D. (2005). New course development in multicultural marketing. Journal of Marketing Education, 27(2), 151-162.

Carter, R., \& Beeton, R. (2004). A model of cultural change and tourism. Asia Pacific Journal of Tourism Research, 9(4), 423-442.

Clarke III, I., Flaherty, T. B., \& Yankey M. (2006). Teaching the visual learner: The use of visual summaries in marketing education. Journal of Marketing Education, 28(3), 218-226.

Craik, J. (2001). Cultural tourism. In N. Douglas, N. Douglas, \& R. Derrett (Eds.), Special interest tourism (pp. 113-139). Brisbane, Chichester: Wiley.

Dann, G. M. S. (1997). Images of destination people in travelogues. In R. Butler \& T. Hinch (Eds.), Tourism and indigenous peoples (pp. 349-375). London: International Thomson Business press. 
Dann, G. M. S. (2002). The tourist as a metaphor of the social world. In G. M. S. Dann (Ed.), The tourist as a metaphor of the social world (pp. 1-17). Oxon: CABI Publishing.

Desmond, J. (1999). Staging tourism. Chicago: The University of Chicago Press.

Dietvorst, A. (1994). Cultural tourism and time-space behavior. In G. Ashworth \& P. J. Larkham (Eds.), Building a new heritage (pp. 69-89). London: Routledge.

Duggan, B. (1997). Tourism, cultural authenticity, and the native craft cooperative: The Eastern Cherokee experience. In E. Chambers (Ed.), Tourism and culture an applied perspective (pp. 31-57). Albany: State University of New York Press.

Eagleton, T. (2000). The idea of culture. Oxford: Blackwell Publishers Ltd.

Echtner, C. M. (1999). The semiotic paradigm: implications for tourism research, Tourism Management, 20, 47-57.

Edson, G. (2004). Heritage: Pride or passion, product or service? International Journal of Heritage Studies, 10(4), 333-348.

Engel, J. F., Blackwell, R. D., \& Miniard, P. W. (2001). Consumer behavior. Mason, $\mathrm{OH}$ : South Western.

Fan, Y. (2000). A classification of Chinese culture. Cross Cultural Management-An International Journal, 7(2), 3-9.

Featherston, M. (1995). Global culture: An introduction. In M. Featherston (Ed.), Global culture (pp. 1-14). London: Sage Publications Ltd.

Fiske, J. (1996). Understanding popular culture. London: Routledge.

Fiske, J. (2001). Introduction to communication studies. London: Routledge.

Flack, A. (2007). Cultural tourism (presentation on market research). London: VisitBritain.

Greenwood, D. (1989). Culture by the pound: An anthropological perspective on tourism as cultural commoditization. In V. Smith (Ed.), Hosts and guests: The anthropology of tourism (pp. 171-198). Philadelphia: Pennsylvania University Press.

Groeschl, S., \& Doherthy, L. (2000). Conceptualising culture. Cross Cultural Management-An International Journal, 7(4), 12-17.

Gronroos, C. (1987). Developing the service offering a source of competitive advantage. In C. Surprenant (Ed.), Add value to your service (p. 83). Chicago American Marketing Association.

Halewood, C., \& Hannam, K. (2001). Viking heritage tourism-Authenticity and commodification. Annals of Tourism Research, 28(3), 565-580.

Hall, S. (1997). Representation: Cultural representations and signifying practices. London: Sage Publications Ltd.

Hill, M. E., \& McGinnis, J. (2007). The curiosity in marketing thinking. Journal of Marketing Education, 29(1), $52-62$.

Hjalager, A., \& Antonioli Corigliano, M. (2000). Food for tourists-determinants of an image. International Journal of Tourism Research, 2(4), 281-293.
Jenks, C. (1995). Culture. London: Routledge.

Kale, S. (1991). Culture-specific marketing communications: An analytical approach. International Marketing Review, 8(2), 18-30.

Kasfir, S. (1999). Samburu souvenirs: Representations of a land in amber. In R. Phillips \& C. Steiner (Eds.), Unpacking culture-art and commodity in colonial and postcolonial worlds (pp. 67-83). Berkeley: University of California Press.

Kennett, B. (2002). Language learners as cultural tourists. Annals of Tourism Research, 29(2), 557-559.

Kim, H. (2005). Nostalgia and tourism. Tourism Analysis, 10(1), 85-88.

Kotler, P., \& Armstrong, G. (2008). Principles of marketing. London: Prentice Hall Europe.

Kotler, P., Armstrong, G., Saunders, J., \& Wong, V. (1999). Principles of marketing. London: Prentice Hall Europe.

Kotler, P., Bowen, J., \& Makens, J. (2006). Marketing for hospitality and tourism. Upper Saddle River, NJ: Pearson Prentice-Hall.

Lawton, D. (1975). Class, culture and the curriculum. London: Routledge \& Kegan Paul.

Lee, S., \& Littrell, M. (2003). Web sites for cultural products marketing potential for US consumers. Journal of Fashion Marketing and Management, 7(4), 356-370.

Leeds-Hurwitz, W. (1993). Semiotics and communication: Signs, codes, cultures. London: Lawrence Erlbaum Associates.

Lloyd, D., \& Thomas, P. (1998). Culture and the state. London: Routledge.

MacDonald, R., \& Joliffe, L. (2003). Cultural rural tourism. Annals of Tourism Research, 30(2), 307-322.

Macleod, D. (2006). Cultural commodification and tourism: A very special relationship. Tourism Culture \& Communication 6(2), 71-84.

McIntosh, A., \& Prentice, R. (1999). Affirming authenticity consuming cultural heritage. Annals of Tourism Research, 26(3), 589-612.

McKercher, B., Ho, P., \& du Cros, H. (2004). Attributes of popular cultural attractions in Hong Kong. Annals of Tourism Research, 31(2), 393-407.

Medina, L. (2003). Commoditizing culture tourism and Maya identity. Annals of Tourism Research, 30(2), 353-368.

Mick, D. G. (1986). Consumer research and semiotics: Exploring the morphology of signs, symbols, and significance. Journal of Consumer Research, 31, 196213.

Middleton, V., \& Clarke, J. (2001). Marketing in travel and tourism. Woburn: Butterworth-Heinemann.

Morales Cano, L., \& Mysyk, A. (2004). Cultural tourism, the state, and Day of the Dead. Annals of Tourism Research, 31(4), 879-898.

Odimu, K. (2002). Cultural tourism in Kenya. Annals of Tourism Research, 29(4), 1036-1047.

Paliwoda, S., \& Thomas, M. (1999). International marketing. Oxford: Butterworth-Heinemann.

Pieterse, J. N. (1995). Globalization as hybridization. In M. 
Featherston, S. Lash, \& R. Robertson (Eds.), Global modernities (pp. 45-68). London: Sage Publications.

Reisinger, Y., \& Mavondo, F. (2006). Cultural differences in travel risk perception. Journal of Travel and Tourism Marketing, 20(1), 13-31.

Reisinger, Y., \& Steiner, C. (2006). Reconceptualizing object authenticity. Annals of Tourism Research, 33(1), 65-86.

Richards, G. (1996a). The scope and significance of cultural tourism. In G. Richards (Ed.), Cultural tourism in Europe (pp. 19-46). Oxon: CABI Publishing.

Richards, G. (1996b). The social context of cultural tourism. In G. Richards (Ed.), Cultural tourism in Europe (pp. 47-70). Oxon: CABI Publishing.

Richards, G., Goedhart, S., \& Herrijgers, C. (2001). The cultural attraction distribution system. In G. Richards (Ed.), Cultural attractions and European tourism (pp. 71-89). Tilburg: CABI Publishing.

Robinson, M. (1999). Cultural conflicts in tourism: Inevitability and inequality. In M. Robinson \& P. Boniface (Eds.), Tourism and cultural conflicts (pp. 1-32). Oxon: CABI Publishing.

Salomon. M. (2001). Realer than real: Retail hyperreality and the encoding of "authentic" cultural symbolism. Advances in Consumer Research, 28, 397.

Shepherd, R. (2002). Commodification, culture and tourism. Tourism studies, 2(2), 183-201.
Silverman, E. (1999). Tourist art as the crafting of identity in the Sepik River (Papua New Guinea). In R. Phillips \& C. Steiner (Eds.), Unpacking culture-art and commodity in colonial and postcolonial worlds (pp. 51-66). Berkeley: University of California Press.

Storey, J. (1996). Cultural studies and the study of popular culture: Theories and methods. Edinburgh: Edinburgh University Press Ltd.

VisitBritain. (2001). Hidden Britain. London: Author.

VisitBritain. (2005a). Funding agreement between the department for culture, media and sport at VisitBritain, 2005/2006-2007/2008. London: Author.

VisitBritain. (2005b). A snapshot of past forward marketing to cultural visitors Conference March 3, 2005, Birmingham, UK.

VisitBritain. (2007a). The golden age. Retrieved May 11, 2007, from http://www.visitbritain.it/campaign/film/thegolden-age/idex.aspx

VisitBritain. (2007b). Visitbritain appoints team Saatchi to review Britain's brand identity. Retrieved October 30, 2007, from http://www.visitbritain.com/en/press/pressreleases/vb-appoints-team-saatchi.aspx

Wallerstein, I. (1995). Culture in the world-system: A reply to Boyne. In M. Featherston (Ed.), Global culture (pp. 63-65). London: Sage Publications Ltd.

Yamashita, S. (2003). Bali and beyond, exploration in the anthropology of tourism. Oxford: Berghahn Books. 
